\title{
Pacific island regional preparedness for El Niño
}

\author{
Ilan Kelman ${ }^{1,2}$ (D)
}

Received: 6 June 2017/ Accepted: 6 October 2017/Published online: 19 October 2017

(C) The Author(s) 2017. This article is an open access publication

\begin{abstract}
The El Niño Southern Oscillation (ENSO) cycle is often blamed for disasters in Pacific island communities. From a disaster risk reduction (DRR) perspective, the challenges with the El Niño part of the ENSO cycle, in particular, are more related to inadequate vulnerability reduction within development than to ENSO-induced hazard influences. This paper analyses this situation, filling in a conceptual and geographic gap in El Niño-related research, by reviewing El Niño-related preparedness (the conceptual gap) for Pacific islands (the geographic gap). Through exploring El Niño impacts on Pacific island communities alongside their vulnerabilities, resiliences, and preparedness with respect to El Niño, El Niño is seen as a constructed discourse rather than as a damaging phenomenon, leading to suggestions for El Niño preparedness as DRR as part of development. Yet the attention which El Niño garners might bring resources to the Pacific region and its development needs, albeit in the short term while El Niño lasts. Conversely, the attention given to El Niño could shift blame from underlying causes of vulnerability to a hazard-centric viewpoint. Instead of focusing on one hazard-influencing phenomenon, opportunities should be created for the Pacific region to tackle wider DRR and development concerns.
\end{abstract}

Keywords Disaster risk reduction · El Niño · ENSO · Islands · Pacific · Vulnerability

Ilan Kelman

ilan_kelman@hotmail.com

1 Institute for Risk \& Disaster Reduction and Institute for Global Health, University College London, Gower Street, London WC1E 6BT, UK

2 University of Agder, Kristiansand, Norway 


\section{Introduction}

The Earth's climate undergoes multiple, interlocked climate cycles, from seasonal to millennial. One multi-year, quasi-periodic cycle is called the El Niño Southern Oscillation (ENSO) which is generally divided into three phases (Glantz 2000, 2001; Philander 1990): (1) El Niño, which is generally termed the "warm" phase and tends to be labelled as having the strongest adverse impacts while being seen as anomalous because it produces weather conditions which are not expected in the seasons in which it manifests; (2) La Ninã, which is generally termed the "cold" phase and is not always seen as being anomalous because it tends to produce weather conditions which are simply more intense than the expected "normal"; and (3) neither, which is generally termed "neutral" or "normal". Weather patterns from around the world are frequently attributed to either the warm or cold phase of ENSO, especially when the El Niño phase occurs.

Consequently, El Niño (more than the La Niña and neutral phases) is often blamed for weather-related hazards - such as floods, droughts, and fires, whether or not this blame is legitimate-especially for Pacific communities, perhaps because El Niño is characterized by environmental changes in the Pacific Ocean (Bjerknes 1966, 1969; Glantz 2000, 2001; Philander 1990). Pacific communities on mainland South America are often highlighted (e.g. Glantz 1979; Eguiguren 1894), while Pacific island communities have received less attention, with Zebiak et al. (2015) documenting how few studies have examined ENSO for Pacific island communities.

ENSO's physical science aspects are well studied (Sarachik and Cane 2010) and have been traced back over past millennia (Marwan et al. 2003). Impacts rightly or wrongly attributed to ENSO_mainly the El Niño phase - are also documented around the world from historic to contemporary times (Davis 2001; Zebiak et al. 2015). Less work has explored how these specific impacts might be avoidable or the relevance of aiming to attribute certain societal impacts to ENSO, with the El Niño phase highlighted because it tends to include the most extreme deviations from long-term average environmental parameters meaning that preparedness and interest typically focus on El Niño. Discussion by Glantz (2000, 2001) and Philander (1990) exemplifies how El Niño is seen as bringing unusual weather which must be prepared for, compared to La Niña bringing more "normal", which includes for some Pacific islands, again indicating how the El Niño phase of ENSO tends to have the most deviations from long-term averages and thus tends to be the focus for preparedness.

This paper builds on such work, contributing to filling in a conceptual and geographic gap in El Niño-related research, by reviewing El Niño-related preparedness (the conceptual gap) for Pacific islands (the geographic gap). This review and analysis are based on all documents found through a search using the keywords "El Niño" or "ENSO", "prepar*" (a wildcard search to capture "preparation", "preparedness", and other variations) or "readiness", and "Pacific" or individual country names (see Sect. 2.1) of (1) the peerreviewed literature and (2) the libraries of documents and projects of the two main regional agencies (see Sect. 2.1). The inclusion of "ENSO" as a keyword ensured that relevant documents would be found even if El Niño is not mentioned specifically.

Many documents found were not considered further, because they dealt with countries not included in this analysis (see Sect. 2.1). As the analysis was being framed based on the document search, wider literature was then introduced to frame the material such as on historical perspectives of the Pacific and on contemporary disaster risk reduction (DRR) including climate change adaptation (CCA). Additionally, further documents were found by checking the reference lists of the material which appeared from the literature search. 
Consequently, the literature search itself formed the baseline, but not the end point, instead using wider framing literature and a snowball approach to cover the topic. Not all material found is cited in this paper which uses illustrative examples to discuss the wider points.

The next section defines the geographic region of interest, the Pacific islands, and further scopes the paper in terms of the meaning of "preparedness". Then, Sect. 3 defines El Niño and its impacts on the Pacific island region. Section 4 analyses preparedness for El Niño in the Pacific island region through understandings of vulnerabilities and resiliences, as framed through DRR. The discussion in Sect. 5 examines El Niño preparedness as DRR as development leading to an exploration in the conclusions of how El Niño has become a hazard-centric constructed discourse which de-emphasizes the need to address vulnerabilities to El Niño and to other hazard drivers. Overall, this paper shows how focusing on El Niño in the Pacific islands region can fail to address the fundamental vulnerability causes of the development problems exposed by El Niño.

\section{Scoping this study}

\subsection{The Pacific islands region}

For this paper, the Pacific island region (Fig. 1) is defined in terms of the two principal intergovernmental organizations which serve Pacific island communities and governments for development and governance: the Secretariat of the Pacific Community (SPC) and the Secretariat of the Pacific Regional Environment Programme (SPREP). SPREP is the region's focal point for CCA. SPC includes SOPAC, its GeoScience Division, which is the region's focal point for DRR. Each of SPC and SPREP has member states, the combined list of which is:

- American Samoa

- Cook Islands

- Federated States of Micronesia

- Fiji

- French Polynesia

- Guam

- Kiribati

- Marshall Islands

- Nauru

- New Caledonia

- Niue

- Northern Mariana Islands

- Palau

- Pitcairn Islands

- Samoa

- Solomon Islands

- Tokelau

- Tonga

- Tuvalu

- Vanuatu

- Wallis and Futuna 
Additionally, Australia, France, Papua New Guinea (PNG), New Zealand, UK, and the USA are included, but those countries are excluded from this analysis due to (1) their different area and population scales from the list above and (2) the large volume of work which already exists for those countries' El Niño-related impacts and preparedness (e.g. Barr 2000 for PNG). By selecting only the countries in the list above, which are the smaller ones, gaps can be identified and a more targeted analysis relevant to smaller islands can be completed. As such, the terminology used in this paper is "Pacific region" or "Pacific islands" referring to the peoples, communities, and governments of the jurisdictions in the above list.

The Pacific islands display complex geopolitics in terms of governments, governance, sovereignty, and non-sovereignty. Some of the Pacific island countries have full sovereignty, such as Fiji and Vanuatu. Tonga is the only Pacific island state which is categorized as never having lost its full sovereignty through colonization, although it was a British Protectorate for part of the nineteenth century and it remains in the Commonwealth. Four colonial powers continue governing some of the Pacific island countries.

The UK retains one Overseas Territory, Pitcairn Islands, although since the territory has neither an airport nor a harbour nor reliable off-island communications, its population of 50-60 effectively self-governs. This situation was brought to the world's attention when

\section{PACIFIC \\ OCEAN}

Northern Mariana

Islands (US)

Guam (ÚS)

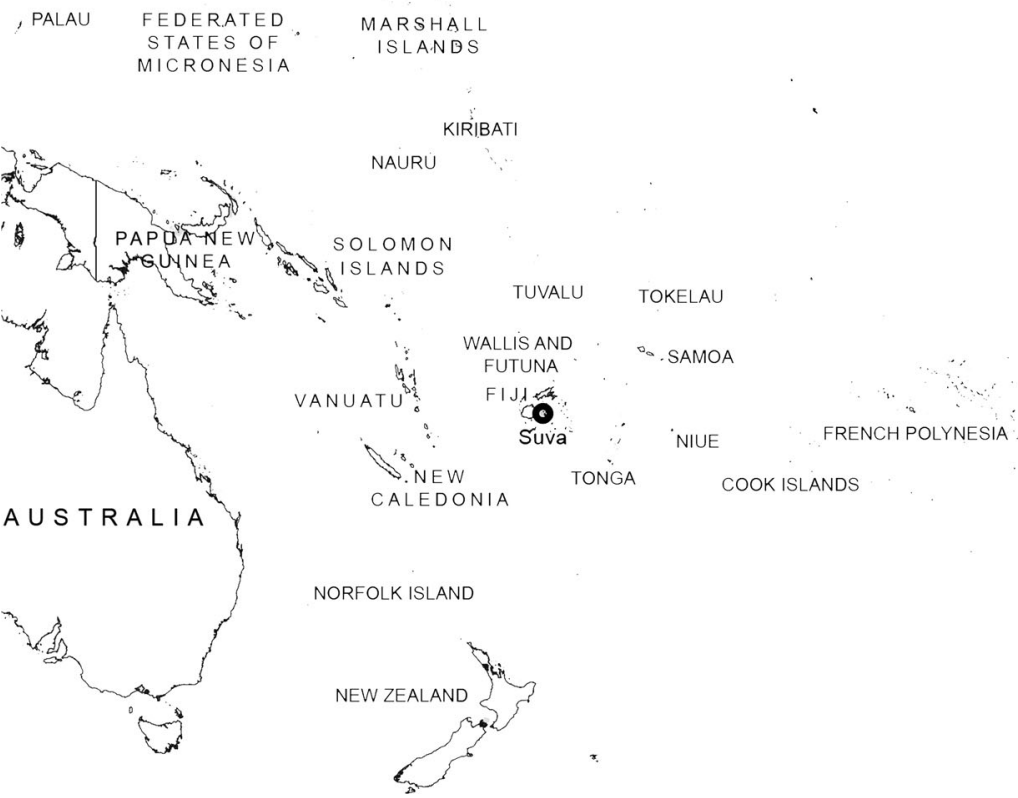

PITCAIRN

Fig. 1 Pacific islands region (based on OCHA/ReliefWeb as per the terms of use at http://reliefweb.int/ map_permission) 
rampant and systematic sexual abuse of girls born on the island led to criminal charges and convictions enacted by a combination of New Zealand's and the UK's judicial systems (Trenwith 2003).

French Polynesia and Wallis/Futuna are Overseas Collectivities of France while New Caledonia is a Special Collectivity of France. Each status confers different governance rights and responsibilities, although little real difference emerges for El Niño-related activities. Uninhabited Clipperton Island in the Pacific Ocean near Central America is governed directly by France.

New Zealand's territories are effectively self-governing, with Wellington taking responsibility for external affairs and defence when requested by the island governments. The terminology used is that Cook Islands and Niue are self-governing in free association with New Zealand, while Tokelau is a self-administering territory, but moving towards free association with New Zealand. In regional fora, such as SPREP and SOPAC, little difference emerges from the sovereign states in dealing with El Niño-related topics.

The US-affiliated Pacific islands are divided into "Flag Territories" (American Samoa, Guam, and Northern Mariana Islands) which are not considered to be sovereign and "the Freely Associated States" (Federated States of Micronesia, Republic of the Marshall Islands (RMI) and Palau) which are considered to be sovereign. Different forms of government within each country lead to differences in receiving and managing funds for governing. In terms of regional interaction for El Niño-related topics, these territories have similar duties and responsibilities. One major difference is that they are all supported by the USA, whereas other Pacific islands generally are not. For example, a recent initiative provides satellite data for El Niño forecasting in only the US-affiliated islands (Luchetti et al. 2016).

Finally, irrespective of what happens in the capital cities, regional centres, and colonial administrations, the dispersion of the Pacific communities means that much happens at the local level. For example, many Pacific island communities are run by a formal governance structure which is not government per se: outer atolls in some Pacific islands such as Anuta in the Solomon Islands have hereditary chiefs in a hierarchical structure but with some degree of relatively communal decision-making (Feinberg 1988). In other places, such as Savo in the Solomon Islands, a system of "Bigmen" (chiefs) and elders govern alongside decision-making from democratically elected representatives who sit in the provincial parliament (Cronin et al. 2004). Any governance approach for El Niño (or other phenomena) must factor in these local approaches for governance with and without formal local government.

This geopolitical diversity impacts relationships between the Pacific islands and the former or current colonial powers at the national and bilateral levels. At the regional level, especially for El Niño-related activities most of which are conducted through SPREP and SOPAC, little day-to-day difference emerges. Instead, the countries are treated equivalently and the non-sovereign countries act as sovereign territories.

\subsection{Experiencing and acting on El Niño in the Pacific}

Given the suggested impacts of El Niño on these Pacific islands, what can and should be done, by the islanders themselves or by others, and what should not be done? The answer to both questions retains a baseline in typical development practices, namely DRR including CCA. DRR is defined as (UNISDR 2009, pp. 10-11): 
The concept and practice of reducing disaster risks through systematic efforts to analyse and manage the causal factors of disasters, including through reduced exposure to hazards, lessened vulnerability of people and property, wise management of land and the environment, and improved preparedness for adverse events.

DRR provides a useful framing within the context of development to deal with El Niño impacts. The reason is that Pacific islands experience El Niño primarily as seasonal-scale changes to their environment, including alterations to the ocean temperature, sea level, precipitation, and winds, in turn affecting plants and animals including fisheries. The effects last several months and deviate from the expected behaviour of the seasons.

The manifestations of these experiences are often described as weather extremes, including wildfires (Siegert et al. 2001), landslides (Marwan et al. 2003), floods and droughts (Dilley and Heyman 1995) leading to famines (Davis 2001), fisheries changes (Glantz 1979), ecosystem impacts (Glynn 1988) including coral bleaching (Normile 2016), and human health impacts (Gueri et al. 1986; Kovats et al. 2003). Sea level varies, exacerbating flooding and wave action on coasts in places where it rises.

In describing these consequences, many media, scientists, and practitioners adopt a disasters-related discourse, suggesting El Niño episodes as causing or manifesting as disasters. For example, the UN Office for Disaster Reduction issued a press release analysing 2015 disasters which blamed El Niño and climate change but which did not mention vulnerability or politics (http://www.unisdr.org/archive/47791). Conversely, Goddard and Dilley (2005) suggest that disaster-related losses are not necessarily more or less during any of the three ENSO phases, seemingly (1) because forecast accuracy improves as the weather becomes more extreme and (2) due to actions taken based on those forecasts, namely standard DRR actions. Dealing with environmental extremes and using techniques such as forecasting, warning, preparing, and mitigating damage are what DRR seeks to achieve.

Two DRR actions are preparedness and readiness. Preparedness is defined as (UNISDR 2009, p. 21):

The knowledge and capacities developed by governments, professional response and recovery organizations, communities and individuals to effectively anticipate, respond to, and recover from, the impacts of likely, imminent or current hazard events or conditions.

Readiness is defined as being related to "preparedness" and as "the ability to quickly and appropriately respond when required" (UNISDR 2009, p. 21). Given the close connection between the two terms, this paper focuses on "preparedness" taking it to encompass "readiness" by definition.

These definitions provide this paper's scope.

\section{El Niño and the Pacific}

\subsection{What is El Niño?}

El Niño is a term collecting a variety of events in which parts of the tropical Pacific Ocean warm above long-term average temperatures. Sea surface temperature changes lead to knock-on effects regarding ocean currents, precipitation, and wind direction and speed, followed by alterations in storm formation and seasons. The changes occur first over the 
wider Pacific region and then, through teleconnections (Bjerknes 1969), elsewhere around the world. El Niño appears approximately every 3-7 years lasting 12-18 months. Each El Niño varies in strength and exact parameters.

Consequently, El Niño is one driver of the weather, climate, and weather- and climaterelated hazards and trends, around the world including Pacific islands. Different types of El Niño emerge with different impacts on climate around the Pacific islands (Murphy and Power 2014). Other drivers simultaneously impact Pacific weather and climate, such as creeping environmental changes, with other monikers being creeping environmental phenomena and creeping environmental problems, referring to environmental conditions changing incrementally but generally being unnoticed, eventually crossing a threshold to lead to a major crisis or catastrophe (Glantz 1994a, b).

One major climate-related creeping environmental change is anthropogenic-influenced climate change. Contemporary climate change is characterized by a comparatively rapid increase in global mean atmospheric temperature, with a significant causative factor being human actions in altering the composition of the Earth's atmosphere, leading to changes in climate parameters from local to global scales (IPCC 2013-14). The Pacific also experiences climate cycles, although no cycle repeats exactly so trends are seen within each cycle. The main example in the Pacific is the Pacific Decadal Oscillation (PDO). The PDO is changes to the North Pacific Ocean's surface temperature lasting a decade or longer with impacts on regional or wider-scale climate (Mantua and Hare 2002). Consequently, El Niño as a driver of climate-related hazards, sometimes termed a hazard spawner (Glantz 2001), interacts with many other creeping processes, trends, and cycles, sometimes making it hard to decouple El Niño's influence from the others (Glantz 2015).

\subsection{El Niño's potential impacts in the Pacific region}

Table 1 compiles some prominent El Niño impacts on climate in Pacific islands from a variety of sources, categorized by country rather than the entire region because countrybased impacts tend to be how the material is reported. Table 1 and its sources are not comprehensive, but are illustrative to set the stage for later discussion explaining the blank cells and differences in the context of regional preparedness.

Table 1 illustrates the challenges of determining El Niño impacts for the Pacific island region. In addition to several blank cells, the descriptions are vague, merely indicating qualitative trends but not describing the degree of the variation, with few quantifications available. Sometimes, the material indicates only the projections for changes in the climate due to a specific El Niño without making it clear whether or not the pattern is generalizable for all El Niños. Sources do not always give the same impacts, so the cells in Table 1 might not fully reflect all citations.

For example, the general assessment of sea level changes in Table 1 includes some countries labelled as "higher" and some countries labelled as "no change". Yet the data processed and reported by Australian Government's Bureau of Meteorology's South Pacific Sea Level and Climate Monitoring Project (e.g. BoM 2010) give a much more complicated and nuanced picture. During the 1997-1998 El Niño, the available sea level gauges in the countries covered here showed:

- Marshall Islands, Solomon Islands, Kiribati, Nauru, Tuvalu, and Samoa measured major decreases.

- Vanuatu, Fiji, and Cook Islands measured small decreases.

- Tonga measured a small increase followed by a small decrease. 
Table 1 Some reported El Niño impacts in Pacific islands

\begin{tabular}{|c|c|c|c|}
\hline Country & Rainfall & Cyclones & Sea level \\
\hline American Samoa & & More frequent & \\
\hline Cook Islands & $\begin{array}{l}\text { More in north } \\
\text { Less in south }\end{array}$ & $\begin{array}{l}\text { More frequent } \\
\text { More intense }\end{array}$ & Higher \\
\hline Federated States of Micronesia & Less & More frequent & Lower \\
\hline Fiji & Less & $\begin{array}{l}\text { More frequent } \\
\text { More intense }\end{array}$ & Lower \\
\hline French Polynesia & & $\begin{array}{l}\text { More frequent } \\
\text { More intense }\end{array}$ & Lower \\
\hline \multicolumn{4}{|l|}{ Guam } \\
\hline Kiribati & More & No change & Higher \\
\hline Marshall Islands & Less & More intense & Lower \\
\hline Nauru & More & & Higher \\
\hline New Caledonia & & No change & \\
\hline Niue & Less & $\begin{array}{l}\text { More frequent } \\
\text { More intense }\end{array}$ & \\
\hline Northern Mariana Islands & Less & & \\
\hline $\begin{array}{l}\text { Palau } \\
\text { Pitcairn Islands }\end{array}$ & Less & No change & \\
\hline Samoa & Less & $\begin{array}{l}\text { More frequent } \\
\text { More intense }\end{array}$ & Lower \\
\hline Solomon Islands & Less & $\begin{array}{l}\text { More frequent } \\
\text { More intense }\end{array}$ & Lower \\
\hline Tokelau & & $\begin{array}{l}\text { More frequent } \\
\text { More intense }\end{array}$ & \\
\hline Tonga & Less & No change & Lower \\
\hline Tuvalu & $\begin{array}{l}\text { More in north } \\
\text { Less in south }\end{array}$ & No change & No change \\
\hline Vanuatu & Less & $\begin{array}{l}\text { More frequent } \\
\text { More intense }\end{array}$ & No change \\
\hline Wallis and Futuna & & $\begin{array}{l}\text { More frequent } \\
\text { More intense }\end{array}$ & \\
\hline
\end{tabular}

Compiled from Annamalai et al. (2015), Glantz (2000, 2001), Shea (2003), Thomson (2009), UNESCAP (2014), UNOCHA (2016) and Wyrtki (1985)

For the 2002-2003 and 2007-2008 El Niños, the sea level gauges, now also including the Federated States of Micronesia, display much more scatteredness, with both increases and decreases in many countries over the El Niño periods.

As such, from the reports and sources in Table 1, accounting for spatial and temporal variation is rarely completed for the Pacific islands. At the local level, significant variations occur due to local conditions superseding or being superseded by the larger-scale influences. For example, coordinated water storage locally can avert adverse drought impacts in a community during reduced rainfall. At the other end of the spatial scale, the Pacific island 
countries have small land areas but some such as Kiribati and Tuvalu are dispersed over vast tracts of the ocean, placing hundreds or thousands of kilometres between islands, permitting climatic variations within the countries and making it hard to characterize El Niño impacts by country.

Additionally, with El Niño lasting 12-18 months, it traverses phases, so climate patterns can shift during that time period. Table 1 indicates suggested overall impacts on climate from El Niño, but temporal differences can emerge with seasons, such as shifts in some places from wetter-than-normal to drier-than-normal as El Niño progresses (Annamalai et al. 2015). Despite changes in tropical cyclone frequency and intensity in some places (Magee et al. 2017), no suggestion is made that out-of-season or near-equator tropical cyclones do or can occur due to El Niño. Even in places where tropical cyclone frequency increases due to El Niño, rainfall is nonetheless less overall and severe droughts are suggested.

Consequently, the understanding of El Niño's climate variations for a specific Pacific island location or a specific country is often too coarse to consider specific impacts and hence to prepare accordingly. Instead, preparedness for a range of conditions is necessary, as is the need to be flexible, in effect articulating a DRR ethos.

\section{Dealing with El Niño}

\subsection{Vulnerabilities and resiliencies}

DRR by definition deals with disaster risk which, by definition, combines hazard and vulnerability (UNISDR 2009). El Niño by definition influences only hazards, while the definition of "disaster risk" attributes the main causative factor of disasters as being vulnerability, which is "the characteristics and circumstances of a community, system or asset that make it susceptible to the damaging effects of a hazard" (UNISDR 2009, p. 30). Also based on UNISDR (2009), resilience is taken to be characteristics which support DRR, keeping in mind that many debates swirl around competing definitions of "vulnerability" and "resilience" (Gaillard 2007, 2010; Lewis 2009, 2013; Mercer 2010; Sudmeier-Rieux 2014) — and, indeed, causative factors of disasters.

Some Pacific island countries such as Fiji (e.g. Méheux et al. 2010) and Tuvalu (e.g. Paton and Fairbairn-Dunlop 2010) have been examined extensively with regard to their vulnerabilities and resiliencies. Others, such as Wallis and Futuna have been the subject of a few scattered and often highly focused studies, such as on land tenure in the context of sea level rise (Worliczek and Allenbach 2011) and creeping environmental changes (Jost 2006), not always mentioning El Niño.

Such community-based studies are difficult to scale up to the Pacific regional level, indicating a tension between taking a regional preparedness approach and supporting communities to help themselves for DRR. This section provides a brief overview of Pacific regional vulnerabilities and resiliencies, and their interconnections, with a focus on El Niño impacts, while recognizing the immense diversity amongst the Pacific island countries in terms of land areas, sea areas, demographics, governance structures, and social services.

Vulnerabilities for the Pacific region emerge due to the islands' comparative isolation, frequent marginalization, small land area, small populations, and limited options for selfcontained land-based livelihoods (e.g. Campbell 2009; Lewis 1999, 2009; Méheux et al. 2007). Consequences include limited internal resources and expertise for DRR, outside 
interests not always being fully aware of or interested in providing assistance, and significant expense for and barriers to mobility-related hazard responses such as evacuation. Despite these traits indicating vulnerability, they frequently yield resilience at the same time (e.g. Baldacchino 2005; Gaillard 2007; Scheyvensa and Momsen 2008), meaning that vulnerabilities and resiliences are neither entirely independent nor exact opposites, instead overlapping and connecting, as frequently noted in the literature (Dahlberg 2015; Fordham 1999; Gaillard 2010; Lewis 2013; Mercer 2010). For Pacific island resiliences, kinship networks yield high levels of trust and strong feelings of identity emerging from small, tight populations, while the small land area alongside natural resource-based livelihoods foster close connections with and understandings of the natural environment, all contributing to DRR.

With their intersecting vulnerabilities and resiliences, many Pacific islands and peoples have long dealt with social and environmental variations, trends, and changes (sometimes wrought entirely by themselves) without external assistance, yielding different levels of success (Campbell 2009; Gaillard 2007; Nunn 2001; Nunn et al. 2007). Many Pacific cultures and communities have lasted centuries, demonstrating long-standing resiliences around the region. Others have disappeared, either moving or being wiped out, showing that vulnerabilities are also prevalent. As isolation diminished in many places in recent times, new DRR and disaster response strategies have been adopted such as remittances, development assistance, and humanitarian aid (Bertram and Watters 1985). Le De et al. (2015) point out that in Samoa, post-disaster remittances have been better than official foreign aid when considering the speed of delivery and how much money reached those affected.

Regarding Pacific island regional preparedness for El Niño, hazard parameters are indeed altered by El Niño. The keys to preparedness are reducing vulnerabilities, many of which have not been addressed; building on and enhancing resiliencies, many of which have long existed for dealing with all environmental fluctuations and extremes; and recognizing the interconnections amongst vulnerabilities and resiliences.

\subsection{Preparedness in the Pacific region}

SPREP and SOPAC, as the regional focal points for DRR and El Niño-related topics, embrace the principal intergovernmental document pertaining to preparedness, the Sendai Framework for Disaster Risk Reduction (SFDRR; UNISDR 2015), as well as other intergovernmental agreements signed in 2015 dealing with climate change, sustainable development, and development financing. These agreements summarize the current state of affairs and goals for top-down approaches to dealing with El Niño-related topics. SFDRR is the only one highlighting DRR and providing a conceptual framework for exploring Pacific regional preparedness through its four priorities:

Priority 1: Understanding disaster risk

Priority 2: Strengthening disaster risk governance to manage disaster risk

Priority 3: Investing in disaster risk reduction for resilience

Priority 4: Enhancing disaster preparedness for effective response and to "Build Back Better" in recovery, rehabilitation, and reconstruction.

These priorities use plenty of jargon which has been theorized and critiqued (e.g. for "Build Back Better", see Williams 2008), but they form the backbone for examining Pacific region initiatives for El Niño preparedness. Because such work has been going on for decades with numerous programmes and donors-and not just confined to the 
intergovernmental organizations, but also conducted by independent researchers and other sectors-it would not be possible to be comprehensive. Instead, illustrative examples are selected to set the stage for discussion, critique, and recommendations.

Priority 1, "understanding disaster risk" with respect to El Niño, is conducted principally through research and analysis, even if not completed primarily for research publication purposes. A summary of research into Pacific regional disaster vulnerabilities and resiliences was provided earlier. When considering disasters which might be linked to El Niño, most of the work is targeted at specific countries or communities, such as original research into Fiji's experiences during the 1997-1998 El Niño (Glantz 2000); coral bleaching in Palau during the same event (Bruno et al. 2001); drought in villages in Vanuatu during the 1994-1995 El Niño (McNamara and Prasad 2014); and Ciguatera (fish poisoning) increasing with El Niño associated sea surface temperature increases around several Pacific islands (Hales et al. 1999).

In the run-up to the 2015-2016 El Niño, SPREP became involved in coral reef monitoring which would have helped to detect bleaching while establishing a data baseline for the future. SOPAC was working on freshwater management in the context of climate variabilities and changes, including El Niño. The risks of El Niño for the Pacific islands are understood at a coarse level, usually articulated in terms of rainfall, drought, and tropical cyclones. The view is thus hazard-centric with it being rare to express risks through a focus on socio-economic and environmental vulnerability for specific locations.

El Niño impacts and vulnerabilities, however, are parts of understanding the disaster risk, with the most evident impacts in the Pacific region being on amount and availability of food and water. Risks to agriculture and fisheries are documented, as are strategies for reducing the associated vulnerabilities (e.g. Campbell 2009, 2015; Lefale 2010; Shea 2003). Given the richness of traditional, local, and external knowledge forms, the knowledge on Pacific island preparedness for El Niño is readily available, from both hazard and vulnerability perspectives.

This knowledge is not always put into action for El Niño preparedness. Macpherson and Macpherson (2017) provide a poignant example with respect to freshwater in Samoa. They point out how El Niño significantly varies annual rainfall in Samoa, but social contexts based on culture, religion, and politics dictate freshwater source ownership, access, and use. Even if forecasting, warning, and planning for freshwater in El Niño were perfect, the disaster risk might still not be managed adequately, because the risk contributions from vulnerabilities based on social structures dominate the risk contributions from hazard parameters. For Samoa, El Niño preparedness should be about working within traditional knowledge and social structures, but it seems often focused on external, technical contributions.

Priority 2 "strengthening disaster risk governance to manage disaster risk" and Priority 3 "investing in disaster risk reduction for resilience" are hard to differentiate on the ground for El Niño and Pacific islands. Governance refers to actions, processes, and systems creating, evolving, and monitoring rules and regulations (e.g. administration, markets, and networks) by which people function within society (Burns and Stöhr 2011; Rosenau and Czempiel 1992). While different theories of and frameworks for disaster risk governance exist, they tend to converge on different expressions of this basic definition of "governance". Notwithstanding the numerous definitions and extensive critiques of "resilience" (e.g. Alexander 2013; Gaillard 2007; Sudmeier-Rieux 2014), much reference to this term also converges on functioning within society, as with governance. Even as "governance" is termed a process and "resilience" is termed a characteristic, the two concepts are neither synonymous nor mutually exclusive. Resilience can be seen as a characteristic of good 
governance while good governance is one process required to achieve resilience. In small communities with a large degree of isolation and self-sufficiency, traits common for Pacific islands, the overlaps and synergies are particularly intense meaning that for a specific hazard-related phenomenon such as El Niño, SFDRR's Priorities 2 and 3 meld.

In the overlap between Priorities 2 and 3, warning systems are an example which cover both disaster risk governance and resilience building. One of the few examples of El Niño warning at the Pacific regional level is from Chowdhury and Chu (2015) looking at sea level forecasts, mainly for the US-affiliated islands and including but not limited to El Niño years. Forecasts have been given 3-6 months in advance, but they report moves towards 6-12 month forecasts due to demand for them.

Earlier work from Kaloumaira (2002) and Lightfoot (1999) discusses early warning and preparedness in Fiji specifically for El Niño. The largest impact is indicated as drought affecting sugar cane. Sugar cane is a cash crop introducing vulnerabilities to Fiji by increasing dependency on external factors such as external markets and international commodity prices while taking away land from more locally based livelihoods. The root causes of El Niño's impacts (as per DRR's definition) are neither identified nor addressed by highlighting sugar cane impacts. While communities could and should make decisions regarding the disaster risks they accept (noting that communities are not homogenous, so sectors or groups within the same community might disagree), which might still entail a choice to grow sugar cane, it can be counterproductive to both Priorities 2 and 3 to assume that sugar cane is the solution for the livelihoods.

Recognizing this situation, Kaloumaira (2002) and Lightfoot (1999) explicitly move away from simply meteorological monitoring for early warning, instead suggesting approaches which would support Fijians irrespective of El Niño. Examples, corroborated later by McNamara and Prasad (2014), are agricultural diversification, avoiding a culture of aid dependency, and dealing with chronic, background levels of malnutrition and water mismanagement. Fletcher et al. (2013) highlight the importance which many Pacific islanders, in Fiji and elsewhere, place on remembering and applying traditional knowledge for warning and food security in the face of El Niño and other climate-related variations and trends. Glantz (2000) notes that the El Niño linked drought in Fiji magnified, but did not cause, ongoing problems of malnutrition and low income. In fact, Kaloumaira (2001) makes the point that the 1997-1998 El Niño hit Fiji so hard partly because it had been preceded by 5 years of many other disasters, so the country never had the time to recover and do better for El Niño. Furthermore, Kaloumaira (2001) points out that the best early warning and preparedness for El Niño occur at the household level, so capacity building needs to be completed at that scale.

Capacity building plays a major role with respect to El Niño. In 2015, South Korea launched a three-year programme to support climate prediction information and skills in the Cook Islands, Federated States of Micronesia, Fiji, Kiribati, Marshall Islands, Nauru, Niue, Palau, Samoa, Solomon Islands, Tonga, Tuvalu, and Vanuatu (and also PNG). Similar work has been continuing since long before, such as Nakalevu (2006) describing a Canadian-funded project on capacity building for climate change for the Pacific and Koop (c. 2000) describing the needed capacity for the planned established of Nauru's National Meteorological and Hydrological Service in 2002.

Clear progression in risk governance and resilience for El Niño is seen from these initiatives, from not having dedicated national agencies for weather, climate, and water to having such agencies plus continual capacity building efforts for it. Irrespective of El Niño, but supporting work for preparedness through DRR, these initiatives continue. The 1st Pacific Islands Regional Climate Outlook Forum was held in Fiji in October 2015 to link 
seasonal climate projections with community-based daily decision-making. Other aspects include linking the water and climate sectors, training for interpreting and using climate forecasts, and DRR capacity development. The Forum culminated in the release of the first regional Pacific statement on El Niño and potential impacts. Additionally, Japan is funding a Pacific Climate Change Centre which is expected to open in 2018.

All these initiatives linked to Priorities 2 and 3 are hazard related. Plenty also exists regarding the vulnerability side, but those programmes are not explicitly linked to El Niño.

Priority 4, "enhancing disaster preparedness for effective response", is acknowledged as a large challenge from previous El Niño experiences in the Pacific. For the 2015-2016 El Niño, many donors indicated their "effective response" as being aid deliveries, such as water to communities in Fiji and food to communities in Vanuatu. Allen (2015) describes UNICEF assisting communities affected by El Niño induced drought, highlighting Vanuatu but then generalizing to the rest of the Pacific. Few specifics are given apart from alluding to food and water deliveries, while the indicated measures seem to be no different to UNICEF's regular day-to-day and year-to-year activities in communities around the region. The focus on communities and the lack of a regional scale response is due to the size of the Pacific region and the dispersiveness of countries and communities leading to many different impacts across vast distances.

It is unclear how different the situation is from non-El Niño time periods. Lightfoot (1999) explains the importance of water delivery to Fijian households during the 1997-1998 drought, but then describes how water deliveries to houses and schools in Fiji occur regularly irrespective of El Niño. Water shortage is chronic and symptomatic of underlying, chronic vulnerabilities which become exacerbated, not created, during an El Niño. Funafuti, Tuvalu experiences significant rainfall variations during El Niño-and sometimes outside of the El Niño time period such as the 2011 drought linked to La Niña and associated with a diarrhoeal outbreak (Emont et al. 2017). Enhancing El Niño preparedness means enhancing all disaster preparedness for all phases, namely DRR including CCA of which a major component is capacity building.

\section{Discussion}

\subsection{El Niño preparedness as DRR as development}

El Niño preparedness at the Pacific regional level is being conducted with two main limitations. First, El Niño-related actions are based on the hazard component of disaster risk. Second, they are put together in piecemeal fashion.

Disaster risk, by definition, comprises hazard and vulnerability leading to DRR's definition (UNISDR 2009), which tackles root causes, which are based in vulnerability. The actions in the Pacific region identified as being related to El Niño and preparedness for it tend to focus on hazards spawned or exacerbated by El Niño. The numerous initiatives aimed at tackling vulnerability and supporting resilience do not usually mention or highlight El Niño, whereas when El Niño manifests, then suddenly a discourse emerges that El Niño is the problem even where the specific hazards are similar with or without El Niño. A disconnect appears to be emerging between hazard and vulnerability with respect to El Niño.

Coral bleaching is as an example. When sea surface temperature rises, as it does around many Pacific islands during an El Niño, a typical response of coral reefs is to be stressed by 
the change in temperature and to die (Pandolfi 2015). Because corals become white when they die, sudden death of a large area of coral is termed "bleaching". When the loss of coral reefs via bleaching is connected to consequences for people and communities through vulnerability, it is principally about reducing tourism income and interfering with nearshore fisheries livelihoods. Since live corals reduce the force of waves and currents, coral bleaching can lead to coastal erosion or coastlines shifting. Coral bleaching is devastating not only for the environment and nature-based tourism, but also for more locally sustainable livelihoods and coastal living.

Corals, though, can recover from mass bleaching after several years if conditions are right, namely if the sea surface temperature cools down after El Niño and if other stressors do not exist. One stressor potentially inhibiting coral recovery from the 2015-2016 El Niño is climate change raising the baseline of sea surface temperature, so after an El Niño, it is harder for corals to recover in the warmer water. Additionally, climate change is increasing the acidity of the oceans when atmospheric carbon dioxide is absorbed by the water and turns into carbonic acid (Pandolfi 2015). Corals being calcium carbonate are expected to be damaged by increased ocean acidity, although the biogeochemistry of coral response to ocean acidification is far from being understood (Edmunds et al. 2016).

Moreover, the vulnerabilities to coral deaths would occur for any reason that corals die, which might include dynamite or cyanide fishing; trawling, dredging, and cutting channels; and invasive species, such as from international shipping or due to changing ecosystems under climate change. Where these human-induced stressors continue or newly appear, coral recovery after an El Niño induced sea surface temperature increase-or other stressors-is impeded.

Consequently, irrespective of a hazard or change in hazard which stresses corals, the vulnerabilities remain the same, so it is unclear whether or not El Niño brings any added value to preparedness for coral die-offs which occur from many reasons. This is especially the case when corals have previously demonstrated their ability to recover after El Niño, but not always after other stressors, such as direct human damage. Coral reefs' ability to deal with climate change, namely increased sea surface temperatures and ocean acidification, is not known (Pandolfi 2015).

Similarly for other hazards, it is unclear whether or not El Niño preparedness brings added value or different actions. Drought was the main Pacific regional concern for the 1997-1998 El Niño, but has long been a Pacific regional concern anyway (Giambelluca et al. 1988), even appearing in many indigenous stories and histories (Roberts 1958), whether linked to El Niño or not. Tropical cyclones are affected by El Niño (Magee et al. 2017), but traditional Pacific knowledge involves DRR for tropical cyclones in Fiji (Campbell 1984) and the Federated States of Micronesia (Schneider 1957), amongst others. Where locations are typically hit by severe storms, El Niño could add to the severity-for instance, through elevated sea level, wind speeds, and rainfall intensity-yet the same DRR tenets remain. Where locations are not typically hit by severe storms, El Niño does not seem to affect tropical cyclone frequency, yet the same DRR tenets remain. Similarly, irrespective of how climate change alters or does not alter Pacific cyclone parameters, the same DRR tenets remain.

Consequently, while El Niño influences some Pacific island hazards, as does climate change, it does not create new hazards and it does not influence Pacific island vulnerability. Consequently, El Niño has limited influence on measures for DRR which includes CCA. This situation was shown by the examples of El Niño preparedness which involved few new actions and little which should not be completed for other reasons related to DRR including CCA, namely for long-term development purposes. 
The creation of Nauru's National Meteorological and Hydrological Service in 2002 (Koop c. 2000) exemplifies the implementation of the strategic approach of DRR for longterm development purposes, thereby also assisting with El Niño preparedness. A strong need for a national agency existed without factoring in El Niño, although El Niño was one added reason, but did not provide extra arguments in favour (or against) creating Nauru's National Meteorological and Hydrological Service. While El Niño has usefulness and usability for highlighting the need for national agencies to identify and prepare for hazard extremes, these services would be needed and would be built with or without El Niño. In the case of Nauru, the service was being created for longer-term strategic reasons, meaning that capacity is needed to provide and maintain the services, as attested to by the number of Pacific climate- and weather-related capacity building and development programmes which do not mention El Niño, often focusing on climate change instead.

This point perhaps identifies the biggest challenge with respect to El Niño preparedness as DRR as development in the Pacific region: lack of continuity and consistency. Programmes and projects have different goals, usually scattered around different objectives using different metrics and indicators, according to how each donor must report back-and often with different combinations of Pacific islands. The work is inevitably short-term, perhaps up to 5 years, but often shorter. This challenge is typical across development contexts, so it is not unique to the circumstances described here. It imbues all the power relations, inequities, and wastefulness which have long been documented around the world with respect to development-related endeavours (e.g. Crush 1995; Cuny 1983; Krüger et al. 2015).

El Niño brings this challenge to the forefront due to its recurrence interval of 3-7 years. When El Niño occurs, it becomes the priority-except that if projects take several months to organize, as often occurs, then El Niño is fading by the time work starts. Meanwhile, other projects on a 1-3-year cycle might find that an El Niño occurrence is outside their scope, partly because an El Niño might be considered to be unlikely to occur during the project's timeframe and partly because the recurrence interval is too long to fully consider an El Niño. DRR can help to bring El Niño into the framing by considering root causes of vulnerability and tackling those over the long-term, so that irrespective of which hazards manifest and irrespective over the timeframe over which those hazards manifest, vulnerability to all hazards is reduced. Then, when a hazard or hazard driver appears, the population is equipped to deal with it—at least, in theory.

DRR progress is being made around the Pacific, especially with respect to climate change, as seen by the creation of the national agencies and their continuing training and programmatic development. The combination of traditional knowledge, local knowledge, and external knowledge has achieved prominence in the food security (Campbell 2015) and in cyclone early warning for Fiji and Tonga (Johnston 2015) amongst other sectors.

As well, some initiatives display impressive and needed continuity, surviving many political cycles and budget fluctuations. The Honolulu-based Pacific ENSO Applications Climate Center (PEAC) was founded in 1994 to research and provide information on ENSO-related climate variability for the American-affiliated Pacific islands (American Samoa, Federated States of Micronesia, Guam, Marshall Islands, Northern Mariana Islands, and Palau, plus Hawaii). PEAC achieves outcomes related to vulnerability reduction through climate forecasting and has used El Niño to push forward longer term and wider climate-related capacity building efforts (Schroeder et al. 2012)—which under some US Presidents, such as George W. Bush and Donald Trump, would be hard to frame from a climate change perspective. This approach is highly strategic, thinking over the long term for reducing the root causes of El Niño-related problems and not just responding 
when an El Niño manifests. PEAC sees dealing with El Niño as part of wider capacity building to support development processes.

Within these wider development contexts - encompassing DRR which includes CCAEl Niño preparedness adds little which is new, similarly to climate change. It might be an impetus or driver towards wider DRR including CCA and development, especially given El Niño's prominence in the media when it manifests and especially since El Niño's signs begin in the Pacific. As such, a question emerges regarding the utility of El Niño for DRR within development (and for CCA within DRR) and how El Niño might be constructed to serve these purposes.

\subsection{El Niño as a constructed discourse}

How should El Niño preparedness fit into Pacific island development work? It might be detrimental through placing focus on the hazard dimension of disaster risk, but it might be advantageous through drawing attention to the need for DRR including CCA and the successes of these endeavours. Actively seeking these advantages and exploiting El Niños for such purposes would have no guarantee of success, but it could be one element amongst several implemented simultaneously and aiming for the same goal through different means. The overall strategy to be pursued is capacity building for development, within which DRR including CCA sits. From the previous section, a tactical way for using the attention given to El Niño is El Niño preparedness as DRR as development. This section explores this approach given El Niño as a constructed discourse.

El Niño becomes a constructed discourse in large part due to the challenges in parameterizing it, in terms of actual onset and end dates as well as identifiable impacts on climate. Consequently, forecasts are necessarily nebulous while pinpointing what El Niño is tangibly and its specific impacts is not straightforward. The usefulness of labelling El Niño and accepting it as a distinct phenomenon for which to be prepared comes mainly from the term's prominence and acceptance. The expression "El Niño" is known and has cultural meaning around the world, including in the Pacific, even if the materiality is hard to discern. With media attention and warnings, Pacific islands can take the opportunity of El Niño as a focuser of attention on disasters (but see the critique of "focusing events" by Thompson 2016) to request assistance and to act-aiming to use any support and actions for longer-term DRR and development work. Focusing on El Niño becomes an opportunity to push the wider DRR agenda as part of longer-term strategic approaches to vulnerability reduction, which must entail placing CCA within DRR (e.g. Cumiskey et al. 2015) and ensuring that CCA neither is ignored nor dominates other DRR activities.

Observing El Niño as a constructed discourse becomes only an observation, not a judgment or a criticism. It is a reality which exists and which can be used to achieve the strategic DRR goals. Two dangers can manifest in deliberately adopting the hazard-centric approach and lending tangibility to the culturally constructed and diffuse notion of El Niño.

First, if El Niño does not happen then people might become complacent, presuming that DRR measures proposed are not needed because El Niño is not happening. In fact, in years without El Niño, an assumption could be that preparedness and DRR are not needed. Springboarding off El Niño to promote DRR including CCA could backfire in imputing that DRR is not needed in the absence of El Niño, a classic problem identified in DRR when adopting hazard-centric approaches or focusing on only actions which influence hazards (e.g. Tobin 1995). 
Second, El Niño is problematized and becomes seen as the main concern. Possible opportunities of or benefits from El Niño are subsumed by the threat-related discourse. In the meantime, El Niño distracts from underlying, chronic challenges of development including DRR implementation, with El Niño being given the blame for already existing challenges such as poverty, inequity, and discrimination. El Niño can serve as a conduit into raising these other topics and bringing vulnerability to the forefront, thereby being an issue to be tackled - or it can bury vulnerability by highlighting the hazards and nature's changes as the problems to be addressed.

Considering drought, earlier discussion demonstrated how droughts have always affected Pacific island communities. Droughts around the Pacific have occurred outside of El Niño-such as in October 2011 when Tokelau and Tuvalu received emergency desalination units because they were running out of drinking water-and not all El Niño events have brought severe drought to Pacific locations. Some droughts perhaps could have been foreseen by taking El Niño as an early warning, but foreseeability would not be consistent, considering that McNamara and Prasad (2014) point out that in the three villages which they studied in Vanuatu, the 1994-1995 drought was labelled as being linked to El Niño, whereas the 2005-2006 drought was not. Furthermore, Pacific islanders are used to dry seasons and storing water (Dillaha III and Zolan 1985), which can be completed as long as a wet season exists.

Shea (2003) describes that droughts in Palau, the Marshall Islands, and the Northern Mariana Islands were especially severe during the 1997-1998 El Niño, devastating agriculture and leading to severe water rationing. There is no doubt that rainfall was significantly lower than average in these locations, but information is not provided regarding how water use might have substantially increased or how water management might have changed since the previous major rainfall deficit. In fact, water use patterns have changed so much in Pacific communities over recent decades, that droughts are about water management and sea level rise salinating freshwater sources in addition to changes in rainfall patterns (White and Falkland 2010; White et al. 2007). It is the same with droughts linked to the 2015-2016 El Niño; mainly the rainfall deficit is discussed, with limited attention given to water management, particularly water demand.

For the 2015-2016 El Niño-related weather changes around the Pacific, Annamalai et al. (2015) highlight two important points. First, the communities affected by a rainfall deficit expect the drought to last approximately 6 months. This time period is the typical length of the dry season. Second, many places in the Pacific were expecting wetter-thannormal weather prior to the drier-than-normal weather. An opportunity exists to seek extra water storage prior to the rainfall deficit. Figures for rainfall around the Pacific in 2016 are still being analysed, but the projections indicate clearly that opportunities exist to implement DRR in order to avoid a drought disaster despite any rainfall deficit, including one which would extend beyond the usual dry season.

These experiences illustrate how much of development including DRR must be localized, because regional climate patterns do not always manifest similarly at the local scales at which communities must respond. The Pacific epitomizes this scale differential given the large distances between and small sizes of the communities. SPREP, SOPAC, and PEAC amongst others do well to bring regional consistency and connections while focusing on localized needs and support. They accept and implement the need for contextualization, applying it in their programmes.

Yet El Niño forecasts tend to be regional because the model resolution does not exist to produce highly localized forecasts. El Niño plays a role in the Pacific consciousness, although it is a construct which does not always have direct usefulness at the community 
scale at which people experience possible impacts and must respond. Even where sea level changes or droughts occur during El Niño, it is not possible to unequivocally attribute the localized observations to El Niño. There might be a dominating influence, a non-dominating influence, or no influence, especially when local water management decisions or local coastal engineering can influence water availability and wave height much more than the strongest El Niños. As discussed above, this situation does not obviate the regional forecasts nor fully dismiss the importance of El Niños, because they garner attention and can galvanize responses.

The importance is recognizing what El Niño does and does not do in order to use it constructively for evoking long-term action which ought to be implemented anyway. Certainly, some countries intone serious concerns about El Niño as a phenomenon and choose to allocate resources to El Niño preparedness. In the Pacific, the US-affiliated islands typically receive money from the US government for such work. Many of the initiatives are little different from DRR, even when framed as being related to El Niño.

PEAC is one example. The Pan-Pacific Education and Communication Experiments by Satellite (PEACESAT; see Duncan and McMaster 2008) run from the University of Hawaii has given video courses for decades, including on climate and weather topics encompassing El Niño. Many programmes-including much training from SOPAC and SPREPrelate to CCA and wider DRR topics, incorporating but not being limited to El Niño. Examples are data collection and storage, developing disaster risk management national action plans, risk assessments, and public education and awareness events and materials.

These approaches are long-term, taking a strategic approach to capacity building across topics rather than creating silos by focusing on one hazard or one hazard driver. They accept that El Niño is not the only climate-related challenge or the only disaster/development challenge. El Niño being episodic (in contrast to climate change which is a trend) can capture attention at the times when it is expected to happen or does happen. Climate change and many social changes are creeping changes rather than episodic or cyclical changes, so they can be present continually in the background leading to small changes, hence not always producing focused attention or specific responses until a crisis threshold is reached (Glantz 1994a, b).

At times, some media representations can make it seem as if El Niño is the most important concern, at least in the short term while an El Niño episode is happening, even where the media connect it to other challenges, such as climate change (see the examples given earlier). Then, problems can result in trying to equate or link El Niño too closely with other phenomena such as climate change. In the discussions of drought during El Niño, much of the advice and discussion could be interpreted as suggesting that droughts do not occur outside of El Niño which is not the case for the Pacific. The severity, duration, and impacts of El Niño droughts compared to non-El Niño droughts have never been analysed for the Pacific as a region or for specific Pacific communities. It is clear that droughts tend to display a multiplicity of causes over different timescales (Glantz and Katz 1977; Wilhite and Glantz 1985) and that El Niño confounds attribution for localized changes.

Additionally, El Niño might not always have been entirely villainous in a Pacific island context, as alluded to earlier regarding the opportunities which El Niño brings. Finney (1985) discusses how El Niño induced changes in the oceanic winds might have supported the colonization of Polynesia. This past advantage holds little currency today, but if El Niño were ever fully characterized, with improved forecasting, then specific locales might be able to garner advantages from it. McPhaden et al. (2006) outlines how society might make better use of El Niño-related benefits. This is the key to El Niño preparedness: To 
ensure that the information is not just warnings for response actions to avert problems, but also that it covers any advantages from El Niño's manifestation to be applied for positive gain. These positive gains should be linked to wider climate-related topics, such as CCA and all DRR.

Because El Niño is a regular, medium-term, quasi-periodic phenomenon, it should not be surprising when it manifests. Preparedness should be part of regular month-to-month, year-to-year, and decade-to-decade considerations. Since such preparedness does not occur in many specific communities, and since El Niño impacts frequently seem to be surprising or to catch communities unprepared (compare with "climate surprise" from Streets and Glantz 2000), there is still much work to be completed, even while determining whether or not El Niño preparedness would be the best framing to achieve long-term development goals across the Pacific.

\section{Conclusions}

El Niño in the Pacific region is said to be of high concern and garners a lot of attention from the media, scientists, and agencies. Much of the scientific attention is due to El Niño originating in the Pacific rather than due to specific impacts within the Pacific. Nevertheless, some documentation describes or warns about Pacific regional El Niño impacts, usually in a rather vague manner without indicating precisely what certain places should expect and how to prepare or respond. When examining the detailed scientific evidence and actual response to El Niño warnings, much at the Pacific regional level relates to expectations and it is difficult to attribute specific impacts to El Niño.

The attention given to El Niño, especially through focusing on assumed anomalies rather than on recurrent problems during the "normal" including aspects of La Niña, could shift blame from underlying causes of vulnerability to a hazard-centric viewpoint. It could also shift blame to a hazard influencer which is quasi-period, not manifesting every year, even when the hazards which it influences appear to different degrees irrespective of El Niño. The distraction of El Niño can degrade vulnerability reduction efforts, but could also be used constructively to pursue a wider DRR and development agenda, tackling the fundamental aspects of uncertain impacts and vulnerability by bouncing off the attention given to El Niño. While a danger exists of DRR being of less interest outside of El Niño times, the key is not to set up a contrast or tension. Instead, recognizing the opportunities which El Niño's attention brings and then trying to move beyond El Niño specific approaches could yield the most successful outcomes by supporting DRR including CCA.

In particular, thinking strategically, the attention which El Niño generates brings resources to, international help for, and awareness of the Pacific region and its development needs. Opportunities exist for the Pacific region to raise the wider DRR and development concerns related to vulnerability reduction-except that this approach is rarely taken. Instead, the responsive mode to El Niño dominates with little impetus evident for tackling underlying socio-economic, political, and cultural sources of vulnerability beyond the standard regional programmes. That is, El Niño is seen as an outside event to be tackled individually, rather than used at the regional level as one more driver towards and opportunity for vulnerability reduction.

Furthermore, El Niño is seen as a short-term concern: Deal with El Niño now, it will fade away in a few months, and then the problems will be solved. This construction comes partly from the media and partly from a hazard focus which entails addressing what is 
happening now rather than thinking about root causes and long time frames. Conversely, chronic vulnerability is about root causes and long time frames, so it is not solved in a matter of months and especially is not solved through one-off initiatives. It requires concerted, continual focus which means DRR: Living with environmental risk.

The Pacific region should consider El Niño — and the entire ENSO cycle - as a hazard influencer in addition to the opportunities emerging from the environmental changes. Nonetheless, given the disaster-related problems even during the neutral or normal phase, it is unclear why any phase within the ENSO cycle is necessarily different from the underlying, chronic, root causes of vulnerabilities in the Pacific region. The key for DRR and development is to be able to deal with variations, anomalies, and extremes, irrespective of the source, rather than aiming to have a special, targeted programme for every single change or potential change in the environment. El Niño and the entire ENSO cycle are part of the typical climate and the typical state of affairs with which Pacific islanders have always had to live.

Acknowledgements This work was made possible through support provided by the Office of US Foreign Disaster Assistance, Bureau for Democracy, Conflict and Humanitarian Assistance, US Agency for International Development, under the terms of Award No. Z12-96974. The opinions expressed in this paper are those of the author and do not necessarily reflect the views of the US Agency for International Development. Mickey Glantz and Robert Ross are thanked for managing and directing the project.

Open Access This article is distributed under the terms of the Creative Commons Attribution 4.0 International License (http://creativecommons.org/licenses/by/4.0/), which permits unrestricted use, distribution, and reproduction in any medium, provided you give appropriate credit to the original author(s) and the source, provide a link to the Creative Commons license, and indicate if changes were made.

\section{References}

Alexander, D. E. (2013). Resilience and disaster risk reduction: An etymological journey. Natural Hazards and Earth Systems Science, 13(11), 2707-2716.

Allen, K. (2015). Children and El Niño: Ensuring that El Niño doesn't have a child's face. UNICEF, New York. http://www.unocha.org/el-ni\%C3\%B1o/about-el-ni\%C3\%B1o/children-and-el-niño. Accessed March 25, 2016.

Annamalai, H., Keener, V., Widlansky, M. J., \& Hafner, J. (2015). El Niño strengthens in the Pacific: Preparing for the impacts of drought. Asia-Pacific Issues, 122, 2-10.

Baldacchino, G. (2005). Successful small scale manufacturing from small islands: Comparing firms benefiting from local raw material input. Journal of Small Business and Entrepreneurship, 18(1), 21-38.

Barr, J. (2000). Papua New Guinea case study. In M. H. Glantz (Ed.), Once burned, twice shy? Lessons learned from the 1997-98 El Niño (pp. 159-175). Tokyo: United Nations University Press.

Bertram, G., \& Watters, R. F. (1985). The MIRAB economy in South Pacific microstates. Pacific Viewpoint, 26(3), 497-519.

Bjerknes, J. (1966). A possible response of the atmospheric Hadley circulation to equatorial anomalies of ocean temperature. Tellus, 18(4), 820-829.

Bjerknes, J. (1969). Atmospheric teleconnections from the equatorial Pacific. Journal of Physical Oceanography, 97(3), 163-172.

BoM. (2010). Pacific country report sea level \& climate: Their present state. Nauru. December 2010. Canberra: BoM (Bureau of Meteorology).

Bruno, J. F., Siddon, C. E., Witman, J. D., Colin, P. L., \& Toscano, M. A. (2001). El Niño related coral bleaching in Palau, Western Caroline Islands. Coral Reefs, 20(2), 127-136.

Burns, T. R., \& Stöhr, C. (2011). The architecture and transformation of governance systems: Power, knowledge, and conflict. Human Systems Management, 30(4), 173-194.

Campbell, J. R. (1984). Dealing with disaster: Hurricane response in Fiji. Honolulu: East-West Center.

Campbell, J. (2009). Islandness: Vulnerability and resilience in Oceania. Shima: The International Journal of Research into Island Cultures, 3(1), 85-97. 
Campbell, J. (2015). Development, global change and traditional food security in Pacific island countries. Regional Environmental Change, 15(7), 1313-1324.

Chowdhury, M. R., \& Chu, P.-S. (2015). Sea level forecasts and early-warning application: Expanding cooperation in the South Pacific. Bulletin of the American Meteorological Society, 96(3), 381-386.

Cronin, S. J., Gaylord, D. R., Charley, D., Alloway, B. V., Wallez, S., \& Esau, J. W. (2004). Participatory methods of incorporating scientific with traditional knowledge for volcanic hazard management on Ambae Island, Vanuatu. Bulletin of Volcanology, 66(7), 652-668.

Crush, J. (Ed.). (1995). Power of development. London: Routledge.

Cumiskey, L., Hoang, T., Suzuki, S., Pettigrew, C., \& Herrgård, M. M. (2015). Youth participation at the third UN world conference on disaster risk reduction. International Journal of Disaster Risk Science, 6(2), 150-163.

Cuny, F. (1983). Disasters and development. Oxford: Oxford University Press.

Dahlberg, R. (2015). Resilience and complexity: Conjoining the discourses of two contested concepts. Culture Unbound, 7(2015), 541-557.

Davis, M. (2001). Late Victorian Holocausts: El Nino famines and the making of the third world. London: Verso.

Dillaha, T. A., III, \& Zolan, W. J. (1985). Rainwater catchment water quality in Micronesia. Water Research, 19(6), 741-746.

Dilley, M., \& Heyman, B. N. (1995). ENSO and disaster: Droughts, floods and El Niño/Southern Oscillation warm events. Disasters, 19(3), 181-193.

Duncan, R., \& McMaster, J. (2008). Impact of ICT on university education in small island states: The case of the University of the South Pacific. In E. M. Favaro (Ed.), Small states, smart solutions: Improving connectivity and increasing the effectiveness of public services (pp. 193-211). Washington, DC: The International Bank for Reconstruction and Development/World Bank.

Edmunds, P. J., Comeau, S., Lantz, C., Andersson, A., Briggs, C., Cohen, A., et al. (2016). Integrating the effects of ocean acidification across functional scales on tropical coral reefs. BioScience, 66(5), $350-362$.

Eguiguren, D. V. (1894). Las Lluvia en Piura [The Rains in Piura]. Boletin del Sociedad Geografica de Lima, 4, 241-258.

Emont, J. P., Ko, A. I., Homasi-Paelate, A., Ituaso-Conway, N., \& Nilles, E. J. (2017). Epidemiological investigation of a Diarrhea outbreak in the South Pacific island nation of Tuvalu during a severe La Niña-associated drought emergency in 2011. American Journal of Tropical Medicine and Hygeine, 96(3), 576-582.

Feinberg, R. (1988). Socio-spatial symbolism and the logic of rank on two Polynesian outliers. Ethnology, 27(3), 291-310.

Finney, B. R. (1985). Anomalous westerlies, El Niño, and the colonization of Polynesia. American Anthropologist, 87(1), 9-26.

Fletcher, S. M., Thiessen, J., Gero, A., Rumsey, M., Kuruppu, N., \& Willetts, J. (2013). Traditional coping strategies and disaster response: Examples from the South Pacific Region. Journal of Environmental and Public Health, 2013, Article ID 264503. https://www.hindawi.com/journals/jeph/2013/264503.

Fordham, M. (1999). The intersection of gender and social class in disaster: Balancing resilience and vulnerability. International Journal of Mass Emergencies and Disasters, 17(1), 15-36.

Gaillard, J. C. (2007). Resilience of traditional societies in facing natural hazards. Disaster Prevention and Management, 16(4), 522-544.

Gaillard, J. C. (2010). Vulnerability, capacity, and resilience: Perspectives for climate and disaster risk reduction. Journal of International Development, 22(2), 218-232.

Giambelluca, T. W., Nullet, D., \& Nullet, M. A. (1988). Agricultural drought on South-Central Pacific islands. The Professional Geographer, 40(4), 404-415.

Glantz, M. H. (1979). Science, politics and economics of the Peruvian anchoveta fishery. Marine Policy, 3(3), 201-210.

Glantz, M. H. (1994a). Creeping environmental problems. The World \& I, June (pp. 218-225).

Glantz, M. H. (1994b). Creeping environmental phenomena: Are societies equipped to deal with them? In M.H. Glantz (Ed.), Creeping environmental phenomena and societal responses to them, proceedings of workshop held 7-10 February 1994 in Boulder, Colorado (pp. 1-10). Boulder: NCAR/ESIG.

Glantz, M. H. (Ed.). (2000). Lessons learned from the 1997-98 El Niño: Once burned, twice shy?. Tokyo: United Nations University Press.

Glantz, M. H. (2001). Currents of change: Impacts of El Niño and La Niña on climate and society (2nd ed.). Cambridge: Cambridge University Press.

Glantz, M. H. (2015). Shades of chaos: Lessons learned about lessons learned about forecasting El Niño and its impacts. International Journal of Disaster Risk Science, 6(1), 94-103. 
Glantz, M. H., \& Katz, R. W. (1977). When is a drought a drought? Nature, 267(5608), 192-193.

Glynn, P. W. (1988). El Nino-Southern Oscillation 1982-1983: Nearshore population, community, and ecosystem responses. Annual Reviews of Ecology and Systematics, 19, 309-345.

Goddard, L., \& Dilley, M. (2005). El Niño: Catastrophe or opportunity. Journal of Climate, 18(5), 651-665.

Gueri, M., González, C., \& Morin, V. (1986). The effect of the floods caused by "El Niño" on health. Disasters, 10(2), 118-124.

Hales, S., Weinstein, P., \& Woodward, A. (1999). Ciguatera (fish poisoning), El Niño, and Pacific Sea surface temperatures. Ecosystem Health, 5(1), 20-25.

IPCC. (2013-2014). Fifth assessment report. Geneva: IPCC (Intergovernmental Panel on Climate Change).

Johnston, I. (2015). Traditional warning signs of cyclones on remote islands in Fiji and Tonga. Environmental Hazards, 14(3), 210-223.

Jost, C. (2006). Risques et enjeux environnementaux et changements sociétaux à Futuna (Pacifique français). Les Cahiers d'Outre Mer, 2001/1(233), 13-28.

Kaloumaira, A. (2001). Fiji country case study: Impacts and responses to the 1997-98 El Niño event. In M. H. Glantz (Ed.), Reducing the impact of environmental emergencies through early warning and preparedness: The case of the 1997-98 El Niño (pp. 91-102). Boulder: National Center for Atmospheric Research.

Kaloumaira, A. (2002). Reducing the impacts of environmental emergencies through early warning and preparedness. The case of El Niño Southern Oscillation (ENSO)_The Fiji case study_(SOPAC Technical Report 344). Suva: SOPAC (South Pacific Applied Geoscience Commission).

Koop, N. L. (c. 2000). A proposal for the establishment of a national meteorological and hydrological service: A report prepared for the government of the Republic of Nauru. Nadi: Pacific Ocean and Atmosphere.

Kovats, R. S., Bouma, M. J., Hajat, S., Worrall, E., \& Haines, A. (2003). El Niño and health. The Lancet, 362(9394), 1481-1489.

Krüger, F., Bankoff, G., Cannon, T., \& Schipper, L. (2015). Cultures and disasters: Understanding cultural framings in disaster risk reduction. Abingdon: Routledge.

Le De, L., Gaillard, J. C., Friesen, W., \& Smith, F. M. (2015). Remittances in the face of disasters: A case study of rural Samoa. Environment, Development and Sustainability, 17(3), 653-672.

Lefale, P. F. (2010). Ua 'afa le Aso Stormy weather today: Traditional ecological knowledge of weather and climate. The Samoa experience. Climatic Change, 100(2), 317-335.

Lewis, J. (1999). Development in disaster-prone places: Studies of vulnerability. London: Intermediate Technology Publications.

Lewis, J. (2009). An island characteristic: Derivative vulnerabilities to indigenous and exogenous hazards. Shima: The International Journal of Research into Island Cultures, 3(1), 3-15.

Lewis, J. (2013). Some realities of resilience: An updated case study of storms and flooding at Chiswell, Dorset. Disaster Prevention and Management, 22(4), 300-311.

Lightfoot, C. (1999). Regional El Niño social and economic drought impact assessment and mitigation study. Suva: SOPAC (South Pacific Applied Geoscience Commission).

Luchetti, N., Sutton, J. R. P., Wright, E. E., Kruk, M. C., \& Marra, J. J. (2016). When El Niño rages: How satellite data can help water-stressed islands. Bulletin of the American Meteorological Society, 97(12), 2249-2255.

Macpherson, C., \& Macpherson, L. (2017). Culture and the commodification of water in Samoa. Asia Pacific Viewpoint, 58(1), 86-98.

Magee, A. D., Verdon-Kidd, D. C., Diamond, H. J., \& Kiem, A. S. (2017). Influence of ENSO, ENSO Modoki, and the IPO on tropical cyclogenesis: A spatial analysis of the southwest Pacific region. International Journal of Climatology, 37(S1), 1118-1137.

Mantua, N. J., \& Hare, S. R. (2002). The Pacific decadal oscillation. Journal of Oceanography, 58(1), 35-44.

Marwan, N., Trauth, M. H., Vuille, M., \& Kurths, J. (2003). Comparing modern and Pleistocene ENSO-like influences in NW Argentina using nonlinear time series analysis methods. Climate Dynamics, 21(3), 317-326.

McNamara, K. E., \& Prasad, S. S. (2014). Coping with extreme weather: Communities in Fiji and Vanuatu share their experiences and knowledge. Climate Change, 123(2), 121-132.

McPhaden, M. J., Zebiak, S. E., \& Glantz, M. H. (2006). ENSO as an integrating concept in Earth science. Science, 314(5806), 1740-1745.

Méheux, K., Dominey-Howes, D., \& Lloyd, K. (2007). Natural hazard impacts in small island developing states: A review of current knowledge and future research needs. Natural Hazards, 40(2), 429-446.

Méheux, K., Dominey-Howes, D., \& Lloyd, K. (2010). Operational challenges to community participation in post-disaster damage assessments: Observations from Fiji. Disasters, 34(4), 1102-1122. 
Mercer, J. (2010). Disaster risk reduction or climate change adaptation: Are we reinventing the wheel? Journal of International Development, 2(2), 247-264.

Murphy, B. F., \& Power, S. B. (2014). The varied impacts of El Niño-Southern Oscillation on Pacific island climates. Journal of Climate, 27(11), 4015-4036.

Nakalevu, T. (2006). Capacity building for the development of adaptation measures in Pacific island countries project. Apia: SPREP (South Pacific Regional Environment Programme).

Normile, D. (2016). El Niño's warmth devastating reefs worldwide. Science, 352(6281), 15-16.

Nunn, P. D. (2001). Ecological crises or marginal disruptions: The effects of the first humans on Pacific islands. New Zealand Geographer, 57(2), 11-20.

Nunn, P. D., Hunter-Anderson, R., Carson, M. T., Thomas, F., Ulm, S., \& Rowland, M. J. (2007). Times of plenty, times of less: Last-millennium societal disruption in the Pacific basin. Human Ecology, 35(4), $385-401$.

Pandolfi, J. M. (2015). Incorporating uncertainty in predicting the future response of coral reefs to climate change. Annual Review of Ecology Evolution and Systematics, 46, 281-303.

Paton, K., \& Fairbairn-Dunlop, P. (2010). Listening to local voices: Tuvaluans respond to climate change. Local Environment, 15(7), 687-698.

Philander, S. G. (1990). El Niño, La Niña, and the Southern Oscillation. New York: Academic Press.

Roberts, R. G. (1958). Te Atu Tuvalu: A short history of the Ellice islands. The Journal of the Polynesian Society, 67(4), 394-423.

Rosenau, J. N., \& Czempiel, E.-O. (1992). Governance without government: Order and change in world politics. Cambridge: Cambridge University Press.

Sarachik, E. S., \& Cane, M. A. (2010). The El Niño-Southern Oscillation phenomenon. Cambridge: Cambridge University Press.

Scheyvensa, R., \& Momsen, J. (2008). Tourism in small island states: From vulnerability to strengths. Journal of Sustainable Tourism, 16(5), 491-510.

Schneider, D. M. (1957). Typhoons on Yap. Human Organisation, 16(2), 10-15.

Schroeder, T. A., Chowdhury, Md R, Lander, M. A., Guard, C. C., Felkley, C., \& Gifford, D. (2012). The role of the Pacific ENSO Applications Climate Center in reducing vulnerability to climate hazards: Experience from the U.S.-affiliated Pacific islands. Bulletin of the American Meteorological Society, 93(7), 1003-1015.

Shea, E. (2003). Living with a climate in transition: Pacific communities plan for today and tomorrow. Honolulu: East-West Center.

Siegert, F., Ruecker, G., Hinrichs, A., \& Hoffmann, A. A. (2001). Increased damage from fires in logged forests during droughts caused by El Niño. Nature, 414(6862), 437-440.

Streets, D. G., \& Glantz, M. H. (2000). Exploring the concept of climate surprise. Global Environment Change, 10(2), 97-107.

Sudmeier-Rieux, K. I. (2014). Resilience-An emerging paradigm of danger or of hope? Disaster Prevention and Management, 23(1), 67-80.

Thompson, D. D. P. (2016). Do catastrophes in poor countries lead to event-related policy change? The 2010 Earthquake in Haiti. Journal of Public Administration and Governance, 6(2) (online). http:// macrothink.org/journal/index.php/jpag/article/view/9370/7765 Accessed July 7, 2016.

Thomson, C. (2009). The regional effects of El Niño in the Pacific. Suva: IFRC Pacific Regional Office.

Tobin, G. A. (1995). The levee love affair: A stormy relationship. Journal of the American Water Resources Association, 31(3), 359-367.

Trenwith, A. (2003). The empire strikes back: Human rights and the Pitcairn proceedings. Journal of South Pacific Law, 7(2). http://www.paclii.org/journals/fJSPL/vol07no2/3.shtml.

UNESCAP. (2014). El Niño 2014/2015: Impact outlook and policy implications for Pacific islands. Bangkok: UNESCAP (United Nations Economic and Social Commission for Asia and the Pacific).

UNISDR. (2009). UNISDR terminology on disaster risk reduction. Geneva: UNISDR (United Nations International Strategy for Disaster Reduction).

UNISDR. (2015). Sendai framework for disaster risk reduction 2015-2030. Geneva: UNISDR (United Nations International Strategy for Disaster Reduction).

UNOCHA. (2016). El Niño. New York and Geneva: UNOCHA (United Nations Office for the Coordination of Humanitarian Affairs). http://www.unocha.org/el-niño/rainfall-and-el-niño and http://www.unocha. org/el-niño/cyclones-and-el-nino Accessed February 26, 2016.

White, I., \& Falkland, T. (2010). Management of freshwater lenses on small Pacific islands. Hydrogeology Journal, 18(1), 227-246.

White, I., Falkland, T., Perez, P., Dray, A., Metutera, T., Metai, E., et al. (2007). Challenges in freshwater management in low coral atolls. Journal of Cleaner Production, 15(16), 1522-1528. 
Wilhite, D. A., \& Glantz, M. H. (1985). Understanding the drought phenomenon: The role of definitions. Water International, 10(3), 111-120.

Williams, S. (2008). Rethinking the nature of disaster: From failed instruments of learning to a post-social understanding. Social Forces, 87(2), 1115-1138.

Worliczek, E., \& Allenbach, M. (2011). Customary land tenure and the management of climate change and internal migration: The example of Wallis island. Land Tenure Journal, 2(11), 131-156.

Wyrtki, K. (1985). Sea level fluctuations in the Pacific during the 1982-83 El Nino. Geophysical Reseach Letters, 12(3), 125-128.

Zebiak, S. E., Orlove, B., Muñoz, Á. G., Vaughan, C., Hansen, J., Troy, T., et al. (2015). Investigating El Niño-Southern Oscillation and society relationships. WIREs Climate Change, 6(1), 17-34. 